
\title{
New Disease Reports \\ First report of Curvularia lunata causing leaf spot of Brassica rapa subsp. pekinensis in Thailand
}

\author{
P. Wonglom ${ }^{1}$, S. Ito ${ }^{2}$ and A. Sunpapao ${ }^{3 *}$ \\ ${ }^{1}$ Faculty of Technology and Community Development, Thaksin University, Phatthalung Campus, Phattalung 93110, \\ Thailand; ${ }^{2}$ Department of Biological and Environmental Science, Graduate School of Science and Technology for \\ Innovation, Yamaguchi University, Yamaguchi 753-8515 Japan; ${ }^{3}$ Pest Management Biotechnology \& Plant Physiology \\ Laboratory and Department of Pest Management, Faculty of Natural Resources, Prince of Songkla University, Hatyai, \\ Songkhla, 90112 Thailand
}

*E-mail: anurag.su@psu.ac.th

Received: 03 Sep 2018. Published: 19 Sep 2018. Keywords: fungal pathogen, ITS, pathogenicity

Leaf spot of cabbage (Brassica rapa subsp. pekinensis cv. Tokyo Bekana) was found during summer (April-August) 2017 on a demonstration field at the Prince of Songkla University, Thailand. The primary symptom was small circular dark spots, $0.1-0.2 \mathrm{~cm}$ in diameter, growing to $0.2-0.5 \mathrm{~cm}$, with dark brown margins (Fig. 1). Disease incidence reached approximately $20 \%$ in the field.

A fungal isolate (TBC03) was obtained from infected plants and a colony was grown on potato dextrose agar. The colony was brown to dark brown. Conidiophores were pale brown, reddish brown to dark reddish brown, septate, unbranched, and 4.5-9 $\mu \mathrm{m}$ thick (Fig. 2). Conidia were fusiform, cylindrical or slightly curved, three-septate, basal and apical pale brown, central cells being larger and darker, 5.4-14.6 × 12.2-22.6 $\mu \mathrm{m}$. Based on morphological characters the fungal isolate was identified as Curvularia lunata. The isolate was deposited in the Culture Collection of the Pest Management Department, Faculty of Natural Resources, Prince of Songkla University, Thailand with accession code PSU-TBC03.

To confirm the identity of the leaf spot pathogen as $C$. lunata, DNA of the fungal isolate was extracted using the mini-preparation method (Saitoh et al., 2006). The nuclear ribosomal internal transcribed spacer (ITS) region was amplified using the ITS1 and ITS4 (White et al., 1990) primer pair. The sequence (Genbank Accession No. LC384896) showed 100\% identity with $C$. lunata (KU844328) and was similar to the ex-neotype of $C$. lunata CBS730.96 (JX256429; Manamgoda et al., 2012). Phylogenetic tree analysis demonstrated that isolate PSU-TBC03 clustered with $C$. lunata (KU844328, JX256430, ex-neotype culture JX256429) (Fig. 3).

To test pathogenicity, five, one-month old cabbages cv. Tokyo Bekana were sprayed with a spore suspension of $C$. lunata $\left(1 \times 10^{6}\right.$ conidia $\left./ \mathrm{ml}\right)$. Development of external symptoms was observed after 1 week on young leaves. The fungal pathogen was re-isolated and its morphology matched $C$. lunata. The pathogenicity test was repeated twice. To our knowledge, this is the first report of C. lunata as a pathogen of cabbage in Thailand.

\section{Acknowledgements}

The authors would like to thank Prince of Songkla University (grant no. NAT610511N), the Japan Society for the Promotion of Science and the National Researcher Council of Thailand Core-to-Core Program. The helpful comments of Dr. Seppo Karrila are gratefully acknowledged.

\section{References}

Manamgoda DS, Cai L, McKenzie EHC, Crous PW, Madrid H, Chukeatirote E, Tan YP, Hyde KD, 2012. A phylogenetic and taxonomic re-evaluation of the Bipolaris - Cochliobolus - Curvularia complex. Fungal Diversity 56, 131-144. http://dx.doi.org/10.1007/s13225-012-0189-2

Saitoh K, Togashi K, Arie T, Teraoka T, 2006. A simple method for a minipreparation of fungal DNA. Journal of General Plant Pathology 72, 348-350. http://dx.doi.org/10.1007/s10327-006-0300-1

White TJ, Bruns T, Lee S, Taylor JW, 1990. Amplification and direct sequencing of fungal ribosomal RNA genes for phylogenetics. In: Innis MA, Gelfand DH, Sninsky JJ, White TJ, eds. PCR Protocols: A Guide to Methods and Applications. New York, USA: Academic Press Inc., 315-322. http://dx.doi.org/10.1016/B978-0-12-372180-8.50042-1]

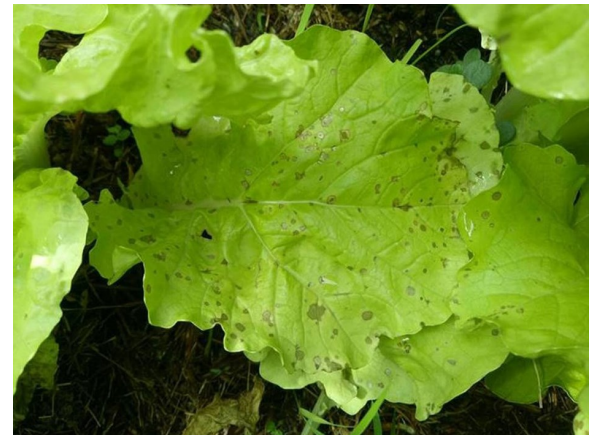

Figure 1

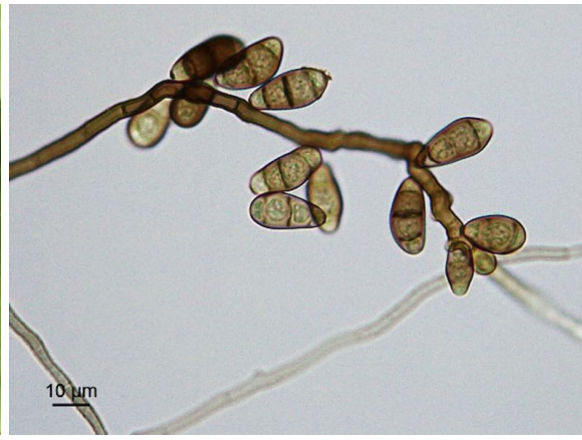

Figure 2
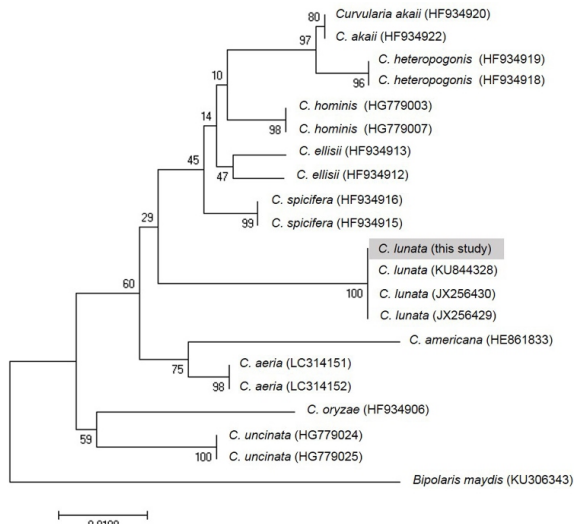

Figure 3

To cite this report: Wonglom P, Ito S, Sunpapao A, 2018. First report of Curvularia lunata causing leaf spot of Brassica rapa subsp. pekinensis in Thailand. New Disease Reports 38, 15. http://dx.doi.org/10.5197/j.2044-0588.2018.038.015 